

\begin{tabular}{lll}
\hline LXIV & ORILLIA, MAY, 1932 & No. 5 \\
\hline \hline
\end{tabular}

\section{CHARLES JAMES STEWART „BE'THUNE, M.A., D.C.L.}

Entomologists and other friends throughout Canada were grieved to hear of the death on April I8th of Dr. C. J. S. Bethune. Although Dr. Bethune was in his 94th year he had retained unimpaired throughout the years that keen mind which was the delight of all who knew him. The end was quite sudden.

Charles James Stewart Bethune was born on his maternal grandfather's farm in West Flamboro Township, Upper Canada, on August I2th, I838. He was the son of the Rev. Alexander Neil Bethune, second Bishop of Toronto, whose father, the Rev. John Bethune, came from Skye to North Carolina in I774 and ministered to a Loyalist regiment during the revolutionary War. After coming to Canada with the Loyalists the Rev. John Bethune opened the first Presbyterian Church in Montreal. His sons, however, attended the Rev. John Strachan's Anglican Church school and were all confirmed in the Church of England.

Dr. C. J. S. Bethune had a distinguished career in the church, in education and in entomology. He graduated from Trinity. College in 1859 , at the age of $2 \mathrm{I}$ with first class honours in classics and mathematics. He received his M.A. degree in $186 \mathrm{I}$ and the degree of D.C.L. in 1883 .

After spending nine years in the Anglican priesthood he became headmaster of Trinity College School, Port Hope, in I87o. He remained in this position until I899. During those years he built the school, rebuilt it after it was destroyed by fire and made it one of the great boys schools of Canada.

In 1906 Dr. Bethune accepted the Chair of Entomology and Zoology at the Ontario Agricultural College. For fourteen years he remained at the head of this department, retiring in October, 1920. During his term of office the work of the department developed greatly and many students passed through his hands who have since done outstanding work in entomology.

All his life Dr. Bethune had been actively interested in entomology. He was largely instrumental in association with Dr. William Saunders, Sir William Osler, Professor Croft, Mr. E. Baynes Reed and others in bringing about the organization of the Entonological Society of Ontario. The Society is really dominion wide in character and was in fact designated at first as the Entomological Society of Canada. When Dr. Bethune went to London from Port Hope the headquarters of the Society were moved to the former city and were similarly moved to the Ontario Agricultural College when Dr. Bethune went there in 1906. Much of the success of the Society and that of the Canadian Entomologist is due to his efforts. He was President of the Society in $187.1-76$, I890-93 and again in the Jubilee year of I9I3. For nearly thirty years he edited the Canadian Eintomologist and the Annual Reports of the Society. 
Many honours came to Dr. Bethune from other scientific societies in various parts of the world. He was a fellow of the Royal Society of Canada and President of Section IV in rgoo. He was a fellow of the American Association for the Advancement of Science and of the Entomological Society of America and President of the latter society in I9I3. He had been honoured by election to Corresponding Membership in many societies.

Dr. Bethune had published a large number of articles on Systematic and Economic Entomology, especially in the Canadian Entomologist and Annual Reports of the Entomological Society of Ontario. He published a number of bulletins on injurious insects and for years prepared the Annual Bibliography of Canadian Entomology for the Transactions of the Royal Society.

Dr. Bethune leaves many friends among entomologists the world over. To him entomology in Canada owes much. His passing severs a tie with the beginning of the science in this country. He has quietly closed a long but very busy and useful life.

\section{THE LIFE-HISTORY OF SCHISTOCERCA LINEATA SCUD.*}

\section{BY NORMAN CRIDDLE,}

Aweme, Man.

The lined grasshopper, Schistocerca lineata Scud., is the only one of the genus met with in the Prairie Provinces, although it has as relations, several famous locusts of the Old World and South America including the desert locust, Schistocerca gregaria Forst., and $S$. paranensis Burm. Indeed there is something in the flight and other actions of this insect which separates it from its associates as an aristocrat and most of us seeing it for the first time would readily proclaim "This is a locust". Despite its aristocratic ancestry, however, the lined grasshopper is little better than a hermit, and in Canada it is restricted in distribution to the southern slopes of a few hot coulies in Alberta.

My steps were first directed to the haunts of this species by Mr. F. S. Carr, of Medicine Hat, Alta. We found it quite near the water on the north shore of the Saskatchewan river. There, the insect was encountered in some numbers, either resting on its favourite food plant, Glycyrrhiza lepidota Nutt., or upon the nearby stones. I also encountered it at the Marias hills in Montana, where it was found on a broad slope facing the south and again frequenting the herbage of the wild liquorice. There is good reason for this choice of a food plant, it being, in reality, one of the few which remains green under the dry conditions prevailing in the haunts of the insect. While, however, this grasshopper remains rather definitely associated with Glycyrrhiza, it does not disdain to feed upon other herbage. In our subsequent rearings, for example, we discovered that the adults would eat species of the genus Astragulus, Lathyrus and Vicia, as well as sweet clover and alfalfa, but that grasses appeared to be less palatable. Finally, when the nymphs hatched, we found that they were quite partial to dandelion. It would seem, therefore, that the food eaten depends somewhat upon its availability.

*Contribution from the Division of Field Crop and Garden Insects, Entomological Branch, Ottawa. 